\title{
The Use of PLDLA/PCL-T Scaffold to Repair Osteochondral Defects in vivo
}

\author{
Andrea Rodrigues Esposito ${ }^{\mathrm{a}, \mathrm{b} *}$, Angelo Carneiro Bonadio ${ }^{\mathrm{a}}$, Nathaly Oliveira Pereira ${ }^{\mathrm{a}}$,
}

Túlio Pereira Cardoso a Maria Lourdes Peris Barbo a, Eliana Aparecida de Rezende Duek ${ }^{\mathrm{a}, \mathrm{b}}$

\author{
${ }^{a}$ Biomaterials Laboratory, Center for Medical and Health Sciences, \\ Catholic University of São Paulo - PUC-SP, Sorocaba, SP, Brazil \\ ${ }^{\mathrm{b}}$ Department of Materials Engineering, Faculty of Mechanical Engineering, \\ State University of Campinas - UNICAMP, Campinas, SP, Brazil
}

Received: March 31, 2012; Revised: August 19, 2012

\begin{abstract}
The physiological repair of osteochondral lesions requires the development of a scaffold that is compatible with the structure of the damaged tissue, cartilage and bone. The aim of this study was to evaluate the biological performance of a PLDLA/PCL-T (90/10) scaffold for repairing osteochondral defects in rabbits. Polymeric scaffolds containing saccharose $(75 \% \mathrm{w} / \mathrm{v})$ were obtained by solvent casting and then implanted in the medial knee condyles of $12 \mathrm{New}$ Zealand rabbits after osteochondral damage with a trephine metallic drill (diameter: $3.3 \mathrm{~mm}$ ) in both medial femoral condyles. Each rabbit received the same treatment, i.e., the polymeric scaffold was implanted on the right side while no material was implanted on the left side (control). Four and 12 weeks later histological examination revealed bone neoformation in the implant group, with the presence of hyaline cartilage and mesenchymal tissue. In contrast, the control group showed bone neoformation with necrosis, exacerbated superficial fibrosis, inflammation and cracks in the neoformed tissue. These findings indicate that the PLDLA/PCL-T scaffold was biocompatible and protected the condyles by stabilizing the lesion and allowing subchondral bone tissue and hyaline cartilage formation.
\end{abstract}

Keywords: biomaterials, PLDLA/PCL-T, osteochondral repair

\section{Introduction}

Arthritis is one of the most common diseases affecting human articulations ${ }^{1}$. The composition of joint cartilage and subchondral bone is important for a joint to work properly since these materials provide a low friction intrajoint environment capable of excellent movement, with lubrication, stability and uniform load distribution, as well as shock absorption during movement ${ }^{2-4}$. Cartilage has an important role in protecting subchondral bone from high stress and diminishes the regular contact pressure 5 . However, cartilage from arthritic joints suffers degradation, resulting in pain, joint rigidity and the loss of movement over time. The limited potential of cartilage for regeneration makes osteoarthritis one of the most important problems in orthopedic surgery. The frequency of osteochondral lesions and osteoarthritis increases with the practice of various sports ${ }^{4}$.

The cause of wearing in joint cartilage and subchondral bone is still unknown. One possibility is that wearing is related to subchondral bone weakening since as bones become less dense so does their ability to support cartilage when transmitting a load to cortical bone. As a result, cartilage fractures increase ${ }^{4}$. These osteochondral defects rarely repair themselves, depending on the type, dimension and location of the damage . $^{3}$.

*e-mail: aesposito@fem.unicamp.br
Tissue regeneration can been divided into three phases, namely, necrosis, inflammation and repair ${ }^{6}$. However, the natural healing of a lesion in joint hyaline cartilage (chondral defect) does not follow these phases, primarily because of the avascular condition of this tissue ${ }^{7,8}$. However, if such damage extends up to subchondral bone (which has adequate vascularization) then all three phases may occur ${ }^{6}$.

There are two major approaches for solving joint cartilage loss or lesions. The first is to repair the lesion by stimulating fibrocartilaginous (or eventually cartilaginous) tissue formation through subchondral bone perforation in the damaged area. However, the neoformed tissue that fills the osteochondral lesion usually differs significantly from normal cartilaginous tissue with regard to its composition, biochemistry, biomechanics and arrangement of inner elements ${ }^{9}$. The lack of perfect integration between the neoformed tissue and cartilaginous tissue enhances the permeability to water. In addition, neoformed fibrocartilaginous tissue has a lower elasticity module compared to cartilaginous tissue $3,10,11$.

The second alternative aims to replace the cartilaginous tissue with material of similar physical and chemical characteristics $^{3}$. Unfortunately, the current therapeutic strategy does not guarantee the restoration of a durable joint surface and has not yet been proven to be effective in preventing osteoarthritis. As a result, most studies have addressed the repair of joint surfaces through tissue 
engineering and the use of porous, three-dimensional synthetic polymeric scaffolds ${ }^{12,13}$.

Polymer characteristics such as topography, chemical composition and surface energy and porosity are essential for biocompatibility ${ }^{14}$. In addition, the material must have favorable biomechanical properties to provide an environment that allows the cells to integrate, differentiate and develop into new tissue ${ }^{15}$. The polymers most widely studied for biomedical applications are poly $(\alpha$-hydroxy) acids, primarily because of suitable properties related to degradation, bioreabsorption and biocompatibility ${ }^{16-18}$.

The copolymer poly(L-co-D,L-lactic acid), PLDLA, combines the mechanical properties of poly(lactic acid) without the long degradation time normally associated with the homopolymer (caused by the high crystallinity of the latter); the higher degradation rate is provided by poly(D,L-lactic acid), although the mechanical properties of this molecule are somewhat inferior to those of poly (lactic acid). By combining the homopolymers it is possible to obtain a product with good mechanical properties and an adequate degradation time for surgical applications ${ }^{19}$. The addition of low molecular mass molecules, such as polycaprolactone-triol (PCL-T), to PLDLA has led to the development of a less hydrophobic polymer by increasing its chain mobility, there by facilitating interaction with the receptor tissue ${ }^{20}$. Based on studies in vitro and in vivo, Esposito $^{21}$ showed that a PLDLA/PCT-T scaffold can be used in cell culturing and tissue engineering because it promotes cellular adhesion and allows tissue growth throughout the scaffold.

The aim of this study was to evaluate the biological performance of a PLDLA/PCL-T scaffold as an implant for osteochondral repair in New Zealand rabbits and to assess its influence on tissue regeneration in vivo.

\section{Experimental}

\subsection{Polymeric scaffold}

Poly (L-co-D,L-lactic acid) PLDLA and polycaprolactone-triol PCL-T solutions (90/10 composition) were obtained by casting in chloroform $\left(10 \% \mathrm{~m} / \mathrm{v}\right.$; Merck $\left.^{\odot}\right)$. After the polymer had completely dissolved, saccharose $\left(75 \% \mathrm{~m} / \mathrm{v}\right.$; Synth $\left.{ }^{\odot}\right)$ was added, with the granularity being limited to $250-500 \mu \mathrm{m}$. The solutions were poured into Teflon molds $4.1 \mathrm{~mm}$ in diameter and $1 \mathrm{~cm}$ high. After solvent evaporation the saccharose was removed with polyvinyl alcohol (PVA)

\subsection{Assessment in vivo}

Twelve New Zealand white rabbits 6 months old were used. The rabbits were anesthetized with an intramuscular injection of ketamine chlorohydrate $\left(30 \mathrm{mg} \cdot \mathrm{kg}^{-1}\right)$ associated with xylazine chlorohydrate $\left(5 \mathrm{mg} \cdot \mathrm{kg}^{-1}\right)$. The femorotibial-patellar joint of both legs was accessed via a medial parapatellar incision done laterally in the joint capsule followed by arthrotomy and lateral dislocation of the patella. By flexing the knee the femoral condyle was exposed and a $3.3 \mathrm{~mm} \times 38.5 \mathrm{~mm}$ trephine metallic drill was used to retrieve an osteochondral cylinder $1 \mathrm{~cm}$ long from the joint cartilage and the subchondral bone of the trochlear sulcus in both femoral medial condyles (right and left leg). Each rabbit received the same treatment, i.e., the polymeric scaffold was implanted on the right leg while no material was implanted on the left leg, kept without treatment (control). The wound was sutured with 4-0 mononylon using simple interrupted stitches in the capsule and simple suturing in the skin ${ }^{7,8}$.

The rabbits were sacrificed 4 weeks and 12 weeks ( $n=6$ to each group) after implantation with an overdose of halothane. The medial femoral condyles and their surrounding tissue were accessed by a medial parapatellar incision and removed for macroscopic examination of tissue repair followed by fixation in Bouin's solution for 24 hours and decalcification in $4.13 \%$ EDTA for two weeks.

This study was approved by the Committee for Ethics in Animal Research at UNIVAP (protocol no. A062/ CEP/2009).

\subsection{Macroscopic evaluation}

The macroscopic analysis was based on seven parameters:

- Repair - healing of the lesion;

- Continuity - leveling of the lesion and integration of the repaired tissues into the surrounding cartilage;

- Surface - presence of hyaline cartilage;

- Brightness - appearance of hyaline cartilage;

- Consistency - performance of the lesion;

- Presence of inflammation; and

- Presence of a visible fracture.

The result was considered to be good (biologically acceptable) when 6-7 of these parameters were satisfactory, or bad (biologically unacceptable) when two or more of these parameters were unsatisfactory.

\subsection{Material processing - histological analysis}

The samples were processed for histological analysis using techniques commonly applied in conventional light microscopy. Sagittal and longitudinal 5 - $\mu$ m-thick sections of the distal femur were stained with hematoxylin-eosin and picrosirius red. The sections were analyzed and photographed with a Nikon ${ }^{\circledR}$ Eclipse E800 polarized light microscope.

For qualitative histological analysis the following parameters were analyzed:

- The type of regenerated tissue (cartilaginous, fibrocartilaginous or fibrous) on the lesion surface;

- The characteristics of the cartilaginous surface (smooth, depressed or irregular);

- Absence or presence of regenerated subchondral bone; and

- Presence of an inflammatory response.

\section{Results and Discussion}

All of the rabbits $(n=12)$ survived until the end of the experiment and showed normal behavior and activities throughout this period. There was no post-operative infection or any evidence of a foreign body reaction. The rabbits showed excellent clinical recovery during the post-operative 
period. Early ambulation was limited to an antalgic gait for two days (on average) followed by a normal gait thereafter.

Macroscopic evaluation showed that all of the rabbits recovered completely from the incision wound without any external scarring. Subsequent examination of the condyles showed that the implanted scaffolds were well-adapted to the tissue, with no apparent rejection, infection or chronic inflammatory response. The pin of one rabbit in the polymer implant group (rabbit \#8-12 weeks) slipped out of the cavity, leaving an empty space; this animal was not included in the analysis of the polymer group.

Histologic repair was considered satisfactory only if the regenerated tissue surface was smooth, covered and level with the surrounding hyaline cartilage. Four weeks after implantation, all condyles from the control group were covered by a large amount of fibrous tissue, in contrast to those with the polymeric scaffold implant, which showed no such formation. Twelve weeks after implantation one rabbit developed an exuberant bony callus on the damaged condyle, as well as fibrous tissue growth around it. This neostructure led to deformation of the condyle and subsequent joint deformation. There were clear differences between the groups in the types of healing tissues they showed. The healing surfaces of untreated lesions (control group) were not uniform and contained depressions that indicated an absence of or only partial filling with cartilage (Figure 1). In some cases, cracks and fissures were observed at the edges where surrounding tissue and healing tissue met. Similar findings were reported by Xie et al. ${ }^{22}$.

Table 1 shows the results of the macroscopic analysis. In this table, $\mathrm{R}$ indicates the right condyle in which the polymeric PLDLA/PCL-T scaffold was implanted, and $\mathrm{L}$ indicates the left condyle (control group) in which no material was implanted in the lesion. The letters $\mathrm{U}$ and $\mathrm{S}$ mean unsatisfactory and satisfactory, respectively.

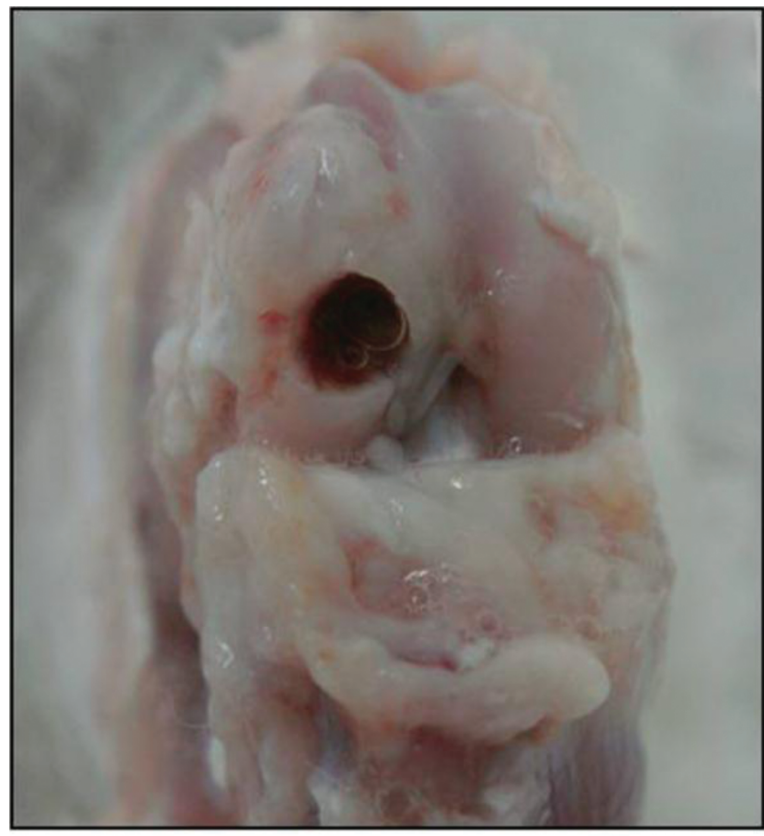

(a)

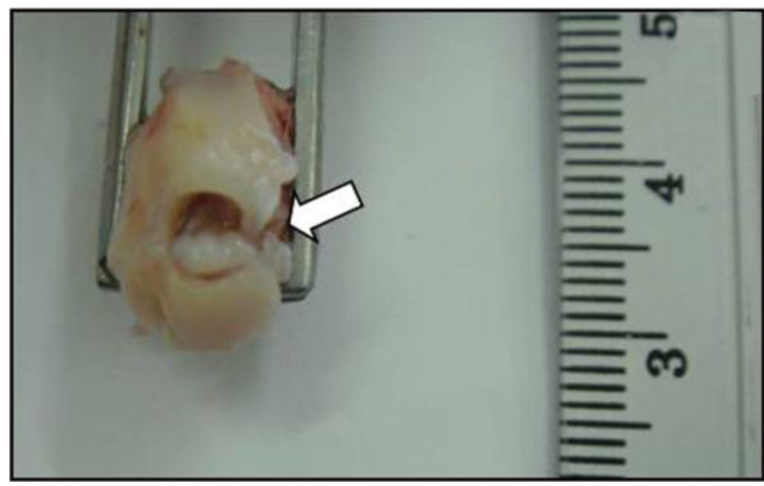

(c)

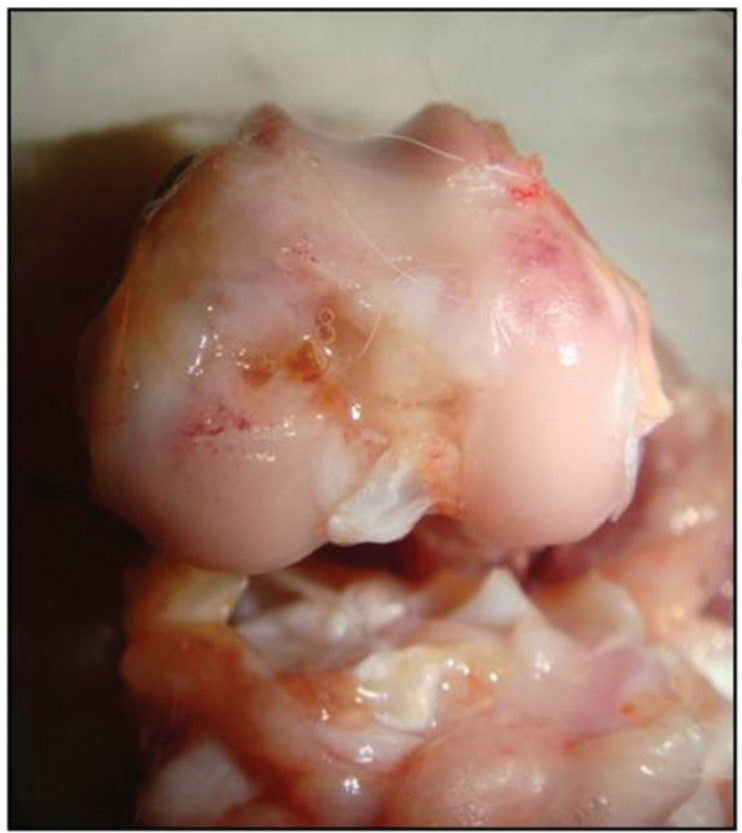

(b)

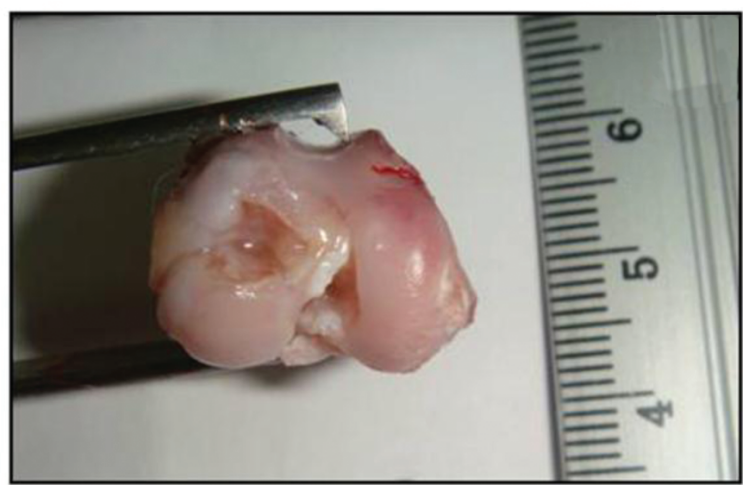

(d)

Figure 1. Macroscopic images showing unsatisfactory healing in the control group. (a) and (c) Discontinuous lesion with a lateral fracture (arrow) seen after four weeks; (b) and (d) Discontinuous lesion containing fibrous tissue seen after 12 weeks. 


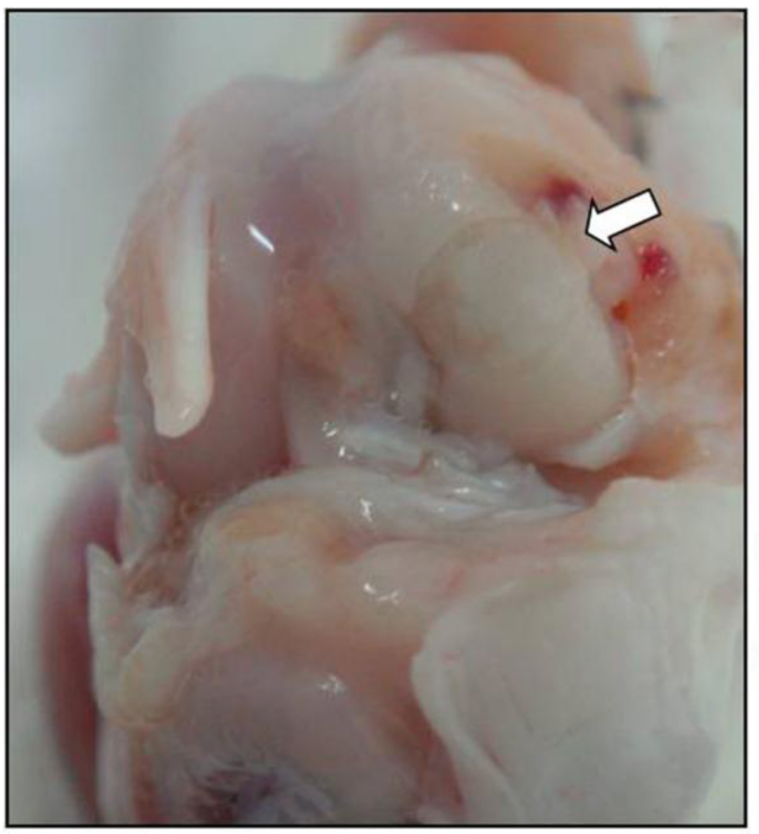

(a)

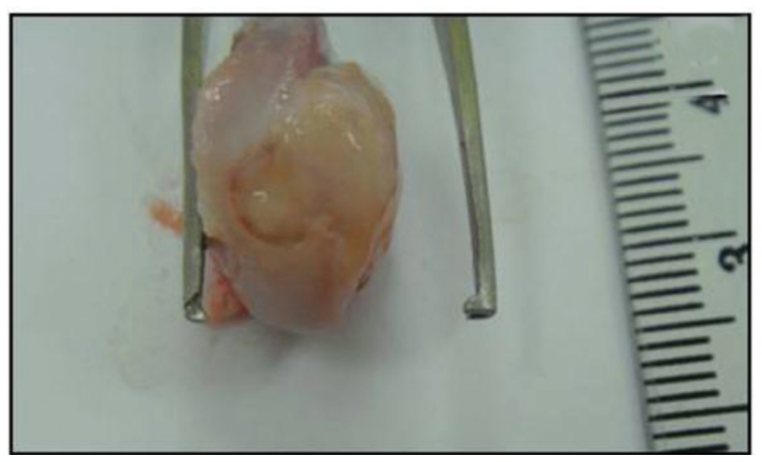

(c)

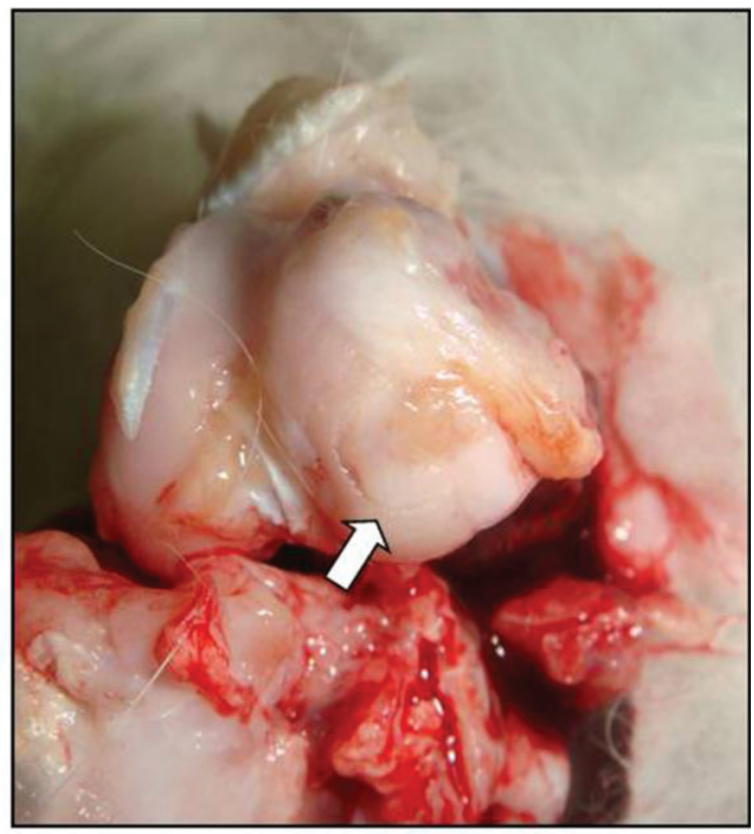

(b)

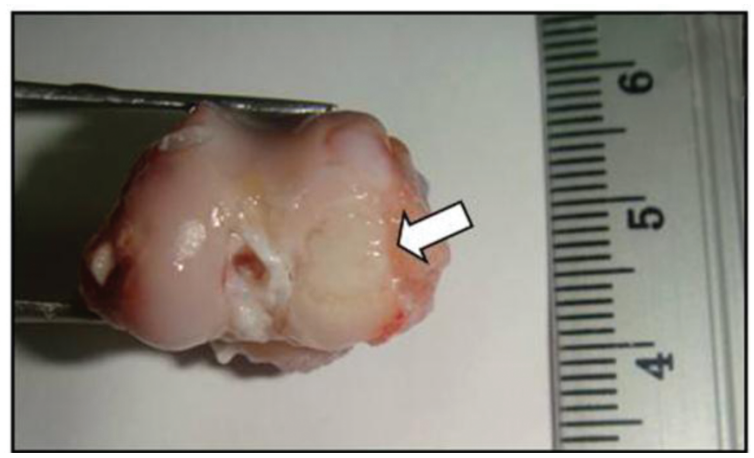

(d)

Figure 2. Macroscopic images showing satisfactory healing in the polymeric implant group. (a) and (c) Partially satisfactory healing after four weeks, showing the polymeric scaffold in the lesion (arrow) (a) and the lesion filled with joint cartilage (c). (b) and (d) Satisfactory healing after 12 weeks showing a lesion that is consistently filled and with a bright, covered surface similar to cartilage (arrow).

Two rabbits showed partially satisfactory results four weeks after polymer implantation in the damaged condyle. In these cases, the polymer showed continuity with the surrounding tissue, as well as consistency and brightness (Figure 2), whereas the control condyles showed 3-4 unsatisfactory items (Table 1).

After 12 weeks, four rabbits in the implant group had six or more satisfactory items (repair, continuity, surface properties and consistency, no inflammation and no fracture), which suggested PLDLA/PCL-T scaffold biocompatibility (Table 1). The only unsatisfactory item was brightness since the regeneration of hyaline cartilage was restricted to the final stage of healing. In contrast, the only satisfactory item after 12 weeks in the control group was consistency, with evident fibrosis and joint surface discontinuity.

After four weeks, fractures were more frequent (four cases) among rabbits in the control group. This finding suggests that the polymeric scaffold had a structural function in stabilizing the fragile damaged area. Two rabbits in the control group had fractures after 12 weeks, whereas no fractures were observed in the implanted group, except for rabbit \#8. However, this rabbit was excluded from the subsequent analysis because the polymeric implant did not remain in the osteochondral lesion as mentioned. This stability in conserving the condylar structure, along with the other parameters analyzed (Table 1), indicated satisfactory healing in condyles with polymeric implants.

The histological analysis of control condyles after four weeks shows foreign body-type reactions with necrosis and an exacerbated inflammatory infiltrate containing multinucleated giant cells and necrotic debris (Figure 3a, b). There were small areas of irregular bone neoformation with a membranous aspect, exacerbated fibrosis and a chronic inflammatory infiltrate with synovial proliferation (Figure 3c). The remaining hyaline cartilage was thin and 
Table 1. Macroscopic evaluation of condyles 4 and 12 weeks after polymer implantation.

\begin{tabular}{|c|c|c|c|c|c|c|c|c|c|}
\hline & & & Repair & Continuity & Surface & Consistency & Brightness & Inflammation & Fracture \\
\hline \multirow{12}{*}{4 Weeks } & \multirow{2}{*}{ Rabbit \#1 } & $\mathrm{R}$ & $\mathrm{U}$ & $\mathrm{S}$ & $\mathrm{U}$ & $\mathrm{S}$ & $\mathrm{U}$ & NO & $\mathrm{NO}$ \\
\hline & & $\mathrm{L}$ & $\mathrm{U}$ & $\mathrm{U}$ & $\mathrm{U}$ & $\mathrm{U}$ & $\mathrm{U}$ & YES & YES \\
\hline & \multirow{2}{*}{ Rabbit \#2 } & $\mathrm{R}$ & $\mathrm{U}$ & $\mathrm{S}$ & $\mathrm{S}$ & $\mathrm{S}$ & $\mathrm{S}$ & NO & NO \\
\hline & & $\mathrm{L}$ & $\mathrm{U}$ & $\mathrm{U}$ & $\mathrm{U}$ & $\mathrm{U}$ & $\mathrm{U}$ & NO & NO \\
\hline & \multirow{2}{*}{ Rabbit \#3 } & $\mathrm{R}$ & $\mathrm{U}$ & $\mathrm{S}$ & $\mathrm{S}$ & $\mathrm{S}$ & $\mathrm{S}$ & NO & NO \\
\hline & & $\mathrm{L}$ & $\mathrm{U}$ & $\mathrm{U}$ & $\mathrm{U}$ & $\mathrm{U}$ & $\mathrm{U}$ & YES & YES \\
\hline & \multirow{2}{*}{ Rabbit \#4 } & $\mathrm{R}$ & $\mathrm{U}$ & $\mathrm{U}$ & $\mathrm{U}$ & $\mathrm{S}$ & $\mathrm{U}$ & YES & YES \\
\hline & & $\mathrm{L}$ & $\mathrm{U}$ & $\mathrm{U}$ & $\mathrm{U}$ & $\mathrm{U}$ & $\mathrm{U}$ & NO & YES \\
\hline & \multirow{2}{*}{ Rabbit \#5 } & $\mathrm{R}$ & $\mathrm{U}$ & $\mathrm{U}$ & $\mathrm{U}$ & $\mathrm{S}$ & $\mathrm{U}$ & $\mathrm{NO}$ & YES \\
\hline & & $\mathrm{L}$ & $\mathrm{U}$ & $\mathrm{U}$ & $\mathrm{U}$ & $\mathrm{U}$ & $\mathrm{U}$ & $\mathrm{NO}$ & NO \\
\hline & \multirow{2}{*}{ Rabbit \#6 } & $\mathrm{R}$ & $\mathrm{U}$ & $\mathrm{S}$ & $\mathrm{U}$ & $\mathrm{S}$ & $\mathrm{U}$ & NO & NO \\
\hline & & $\mathrm{L}$ & $\mathrm{U}$ & $\mathrm{U}$ & $\mathrm{U}$ & $\mathrm{U}$ & $\mathrm{U}$ & NO & YES \\
\hline \multirow{12}{*}{12 Weeks } & \multirow{2}{*}{ Rabbit \#7 } & $\mathrm{R}$ & $\mathrm{S}$ & $\mathrm{S}$ & $\mathrm{S}$ & $\mathrm{S}$ & $\mathrm{U}$ & NO & NO \\
\hline & & $\mathrm{L}$ & $\mathrm{U}$ & $\mathrm{U}$ & $\mathrm{U}$ & $\mathrm{S}$ & $\mathrm{U}$ & NO & NO \\
\hline & \multirow{2}{*}{ Rabbit $\# 8^{*}$} & $\mathrm{R}^{*}$ & $\mathrm{U}$ & $\mathrm{U}$ & $\mathrm{U}$ & $\mathrm{U}$ & $\mathrm{U}$ & $\mathrm{NO}$ & YES \\
\hline & & $\mathrm{L}$ & $\mathrm{U}$ & $\mathrm{U}$ & $\mathrm{U}$ & $\mathrm{S}$ & $\mathrm{U}$ & NO & NO \\
\hline & \multirow{2}{*}{ Rabbit \#9 } & $\mathrm{R}$ & $S$ & $\mathrm{U}$ & $\mathrm{U}$ & $\mathrm{S}$ & $\mathrm{U}$ & YES & $\mathrm{NO}$ \\
\hline & & $\mathrm{L}$ & $\mathrm{U}$ & $\mathrm{U}$ & $\mathrm{U}$ & $\mathrm{U}$ & $\mathrm{U}$ & YES & YES \\
\hline & \multirow{2}{*}{ Rabbit \#10 } & $\mathrm{R}$ & $\mathrm{S}$ & $\mathrm{S}$ & $\mathrm{S}$ & $\mathrm{S}$ & $\mathrm{S}$ & NO & $\mathrm{NO}$ \\
\hline & & $\mathrm{L}$ & S & $\mathrm{U}$ & $\mathrm{U}$ & $\mathrm{S}$ & $\mathrm{U}$ & $\mathrm{NO}$ & $\mathrm{NO}$ \\
\hline & \multirow{2}{*}{ Rabbit \#11 } & $\mathrm{R}$ & $S$ & $\mathrm{~S}$ & $\mathrm{~S}$ & $S$ & $\mathrm{U}$ & $\mathrm{NO}$ & $\mathrm{NO}$ \\
\hline & & $\mathrm{L}$ & $\mathrm{U}$ & $\mathrm{U}$ & $\mathrm{U}$ & $\mathrm{S}$ & $\mathrm{U}$ & YES & $\mathrm{NO}$ \\
\hline & \multirow{2}{*}{ Rabbit \#12 } & $\mathrm{R}$ & S & $\mathrm{S}$ & $\mathrm{S}$ & $\mathrm{S}$ & $\mathrm{S}$ & NO & $\mathrm{NO}$ \\
\hline & & $\mathrm{L}$ & $\mathrm{U}$ & $\mathrm{U}$ & $\mathrm{U}$ & $\mathrm{S}$ & $\mathrm{U}$ & $\mathrm{NO}$ & YES \\
\hline
\end{tabular}

disorganized, and showed fissures and bone sequestration with the presence of hyperplasic chondroblasts. The mature/young bone interface showed an irregular pattern of endochondral ossification and superficial fibrosis. The fibrous tissue was surrounded by rays of striated musculature that suggested rupture of the joint capsule.

Histological analysis of the PLDLA/PLC-T implants after four weeks showed trabecular bone neoformation and the presence of mesenchymal tissue filling the lesion (Figure 4). This tissue consisted of long cells, blastic cells, a few collagen fibers and abundant fundamental amorphous substance. There was no evidence of giant cells associated with a foreign body reaction, thus indicating excellent polymer compatibility. The biocompatibility of mechanical devices is strongly influenced by the degradation rate of the material used since this determines the type and intensity of the inflammatory response $\mathrm{e}^{23}$.

Figure 5 provides histological images from the control group after 12 weeks. There was bone neoformation with extensive superficial fibrosis (Figures 5a, b). Along the edges of the surface synovial membrane there was cellular proliferation and a chronic inflammatory response. Only two cases showed hyaline cartilage, although the joint surface was fibrotic (Figure 5c, d). One condyle showed bone neoformation on the surface, with fibrosis and bone sequestration suggestive of necrotic post-fracture remains observed in the four-week interval.

Twelve weeks after PLDLA/PCL-T scaffold implantation there was bone regeneration that included trabecular bone with beams in the medulla (Figure 6a, c). The joint surface had an extensive covering of mature hyaline cartilage that advanced along the edges (Figures 6b, d); a superficial area with fibrosis was also observed. There was no inflammatory infiltrate. The bone diaphysis had an endochondral pattern of bone neoformation with foci of cartilage. This uneven cartilage distribution resulted in a mixture of thin and thick (hyperplasic) areas, all of them with evident bone neoformation.

In the last decade, huge steps forward have been made in the field of cartilage regeneration. The treatment of osteochondral lesions that involve load-supporting joints, especially the knee, is a great challenge for orthopedics, mainly because of the characteristics of hyaline joint cartilage $^{8}$. When such wounds result in large lesions, the bone tissue is incapable of repair and generates fibrous tissue that results in a loss of mechanical function ${ }^{24}$.

The most recent trend for treating chondral/osteochondral lesions is based on the application of smart biomaterials that could lead to "in situ" regeneration of not only cartilage, but also subchondral bone, preferably through a single step procedure to reduce the costs and the morbidity for the patient. This innovative approach is currently under investigation as several scaffolds have been proposed in clinical practice, with or without the aid of cells ${ }^{25}$.

The velocity of degradation and the extent of the foreign body reaction are determined by the initial molar mass and chemical composition of the material. Clinically, the absorption of poly(glycolic acid) PGA and poly(lactic acid) 


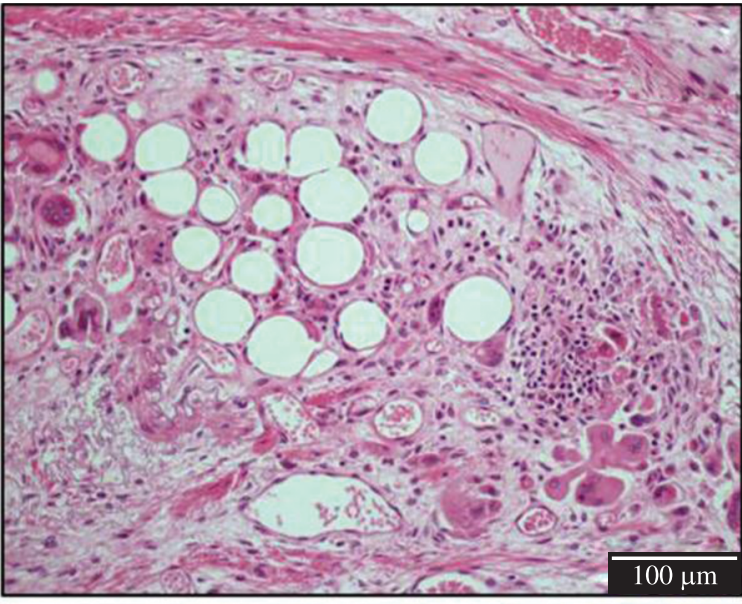

(a)

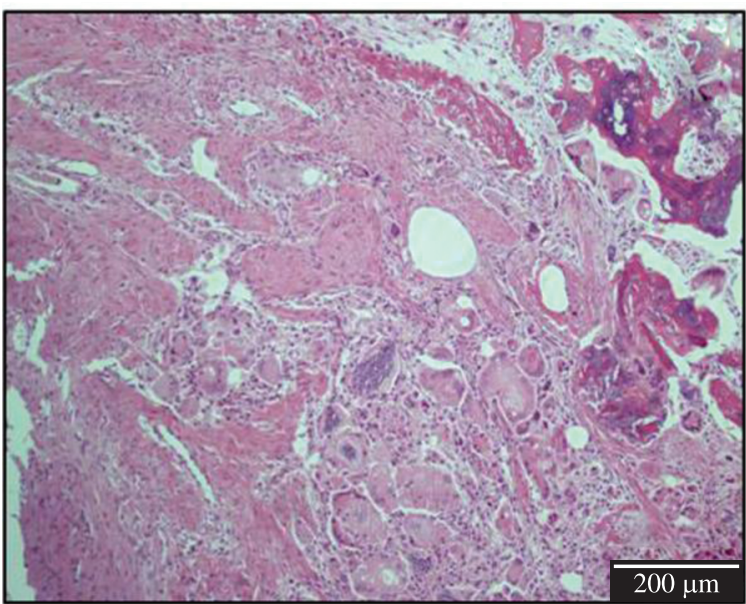

(c)

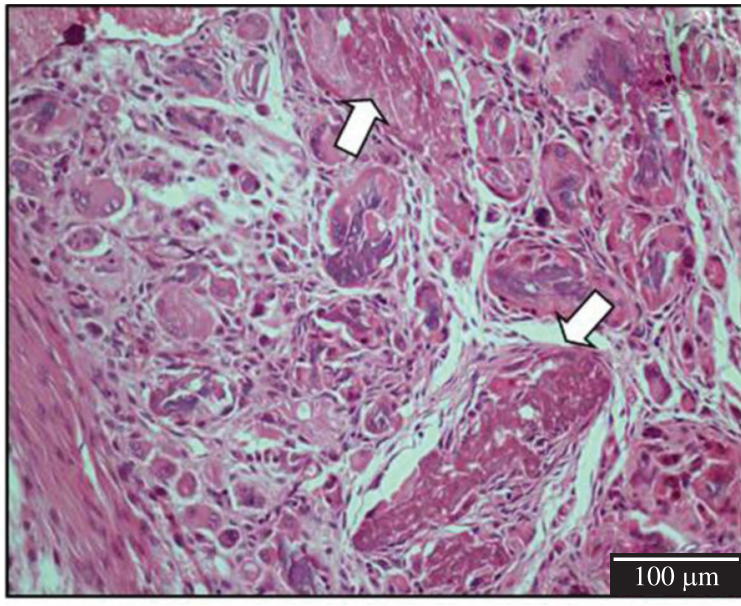

(b)

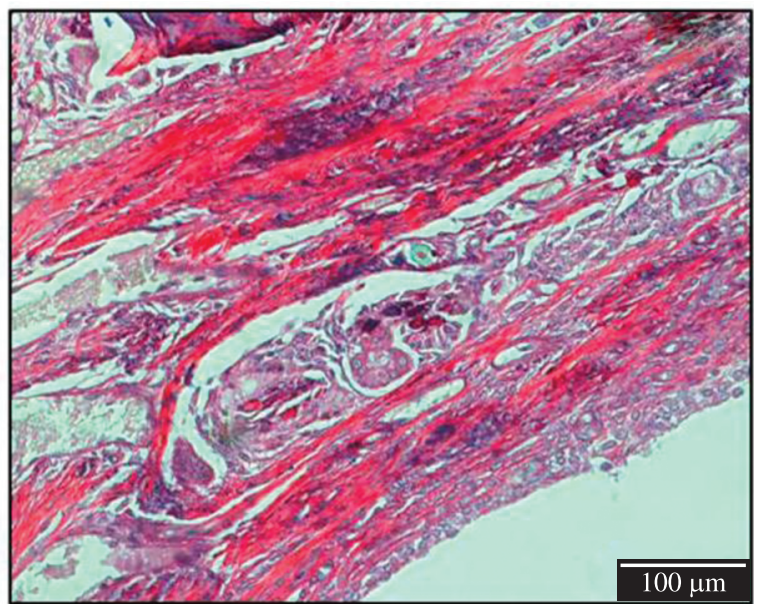

(d)

Figure 3. Histological analysis of control lesions (untreated) after four weeks. (a), (b) and (c): HE staining; (d) Picrosirius red staining. Note the formation of fibrous tissue and the intense inflammatory response in all samples, with the presence of giant cells associated with a foreign body reaction and bone necrosis (arrow).

(PLA) polymers and their copolymers such as PLDLA is frequently accompanied by a local foreign body reaction, especially if degradation is fast or if the polymers are not completely absorbed. However, this reaction is of minimal importance for tissue neoformation since it disappears after the complete degradation and bioreabsorption of the polymer $^{18,20,21,26-29}$.

Porous scaffolds can be prepared by several techniques and have a useful morphology for tissue engineering since their porosity provides physical space for cell growth and colonization. This in turn can contribute to the organization of structures similar to tissues, thereby providing a provisory scaffold for tissue regeneration $^{30}$. In addition, cells adhered to the scaffold are subject to mechanical pressure that can stimulate the production of new bone matrix ${ }^{4,13}$.

Emans et al. ${ }^{31}$ have examined the effect of pore size and pore interconnectivity on cartilage repair in osteochondral defects treated with different scaffolds, using a compression moulding (CM) and a three-dimensional fibre (3DF) deposition technique. Three months post-implantation, cartilage repair was significantly improved after implantation of a 3DF scaffold compared to a CM scaffold. Although not significant, Mankin scores for osteoarthritis (OA) indicated less $\mathrm{OA}$ in the $3 \mathrm{DF}$ scaffold group compared to empty defects and CM-treated defects. It is concluded that scaffold pore size and pore interconnectivity influences osteochondral repair and a decreased pore interconnectivity seems to impair osteochondral repair.

According to Mikos et al. ${ }^{32}$, the rate of cell penetration and growth in polymeric bioreabsorbable porous structures is directly related to the pore size and distribution in the material and varies according to the size of the invading cells and the properties of the implant.

The development of new biocompatible materials that can stimulate good adhesion, growth and cell differentiation is a challenge since such material must temporarily replace the mechanical function of bone and degrade at a rate equivalent to that for tissue regeneration ${ }^{24}$. Shapiro et al. ${ }^{33}$ described the process of osteochondral repair in rabbits with lesions that reached the spongy bone. 


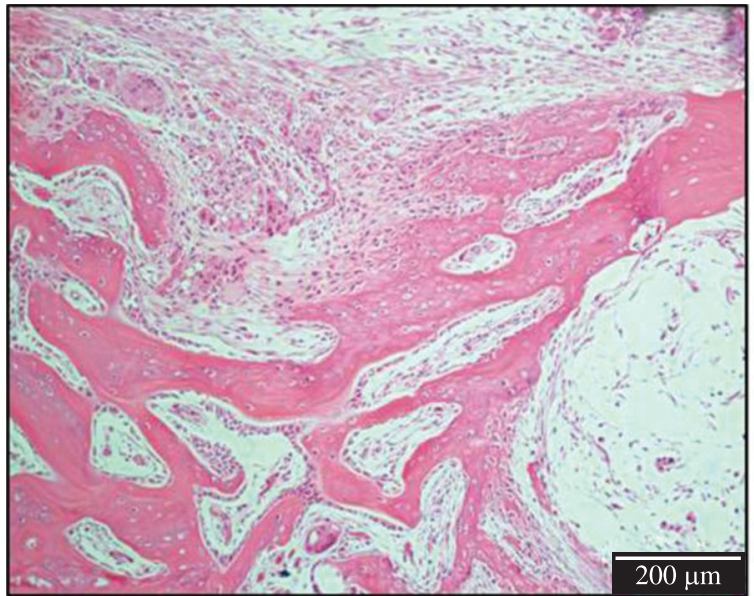

(a)

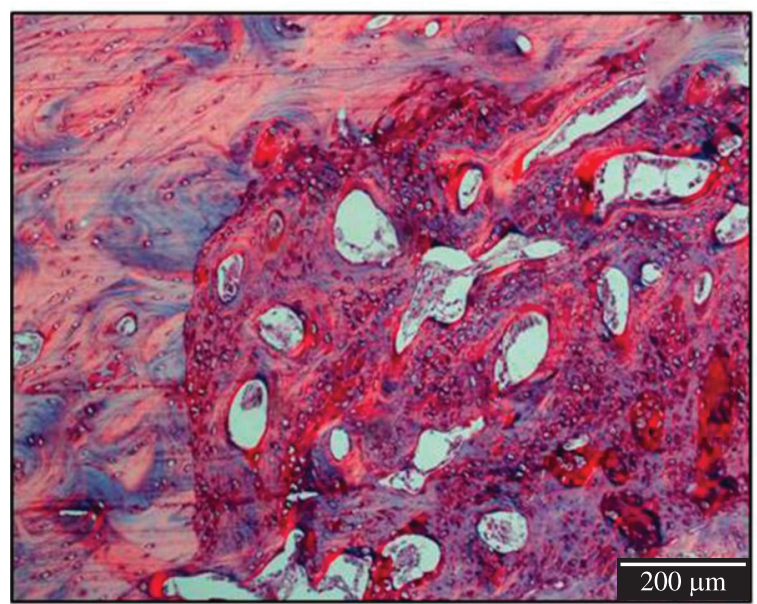

(c)

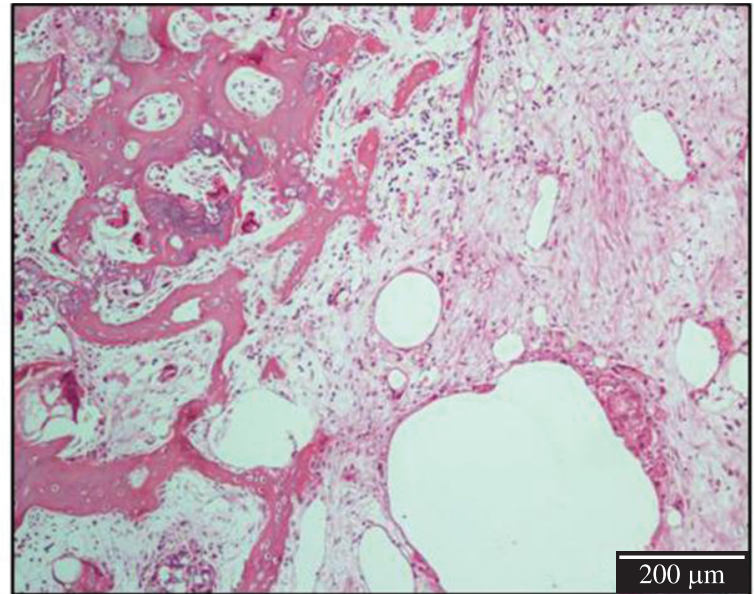

(b)

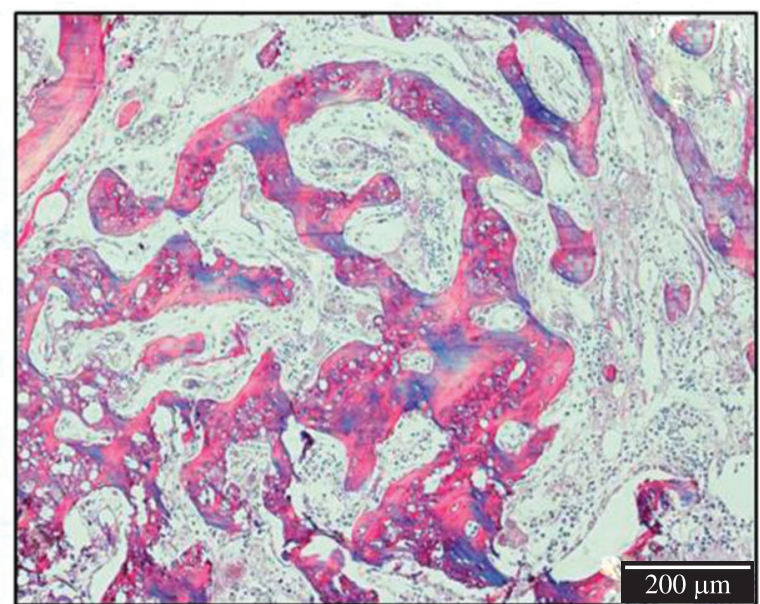

(d)

Figure 4. Histological analysis of lesions with the PLDLA/PCL-T scaffold four weeks after implantation. (a) and (b) HE staining; (c) and (d) Picrosirius red staining. Note the presence of bony neotissue with thin trabeculae surrounded by osteoblasts, the formation of mesenchymal tissue and the absence of giant cells normally associated with a foreign body reaction.

Initially, the blood clot was replaced by a web of fibrin with capillary proliferation from the surrounding bone marrow. Mesenchymal cells invaded the clot periphery and spread over the tissue being repaired. Superficially, a fibrous layer with collagen fibers parallel to the joint surface was formed. Deeper in the lesion, mesenchymal cells differentiated into chondroblasts. As cell differentiation proceeded the tissue under repair developed an aspect similar to hyaline cartilage. Endochondral ossification and the intramembranous formation of osteoid, both of which are involved in subchondral bone replacement, occurred in the deepest region of cartilage in repair. The osteochondral and subchondral bone junction with lamellar bone was repaired 24 weeks after surgery.

Prevention of the degeneration of affected joints is clinically important for the repair process. Shapiro et al. ${ }^{33}$ suggested that the ability to maintain cartilage intactness in a healing joint depends on the reconstitution of excised bone tissue. Cartilage undergoing repair did not show the degenerative alterations observed in most of the 24-week post-operatory failures, except for a small number of animals in which subchondral bone was reconstructed ${ }^{7}$.

Histological analysis revealed the nature of the neoformed tissue for each type of repair. The poor repair of untreated lesions (control rabbits) reflected mainly the retardation of subchondral bone formation and the presence of necrosis at four weeks, possibly because of the high number of fractures. These findings indicate the importance of subchondral bone in tissue reorganization. The predictability of cartilaginous tissue formation in the treated lesions and the predominance of fibrous tissue in the untreated lesions agree with the findings of others authors ${ }^{34}$.

Our results agree with other reports showing that a four-week interval after implantation is insufficient for osteochondral regeneration; in this period, only the initial performance of the scaffold and the occurrence of an inflammatory response can be evaluated ${ }^{35-38}$. In contrast, bone neoformation is readily observed 12 weeks after the implantation of PLGA and PLLA ${ }^{18,35}$. 


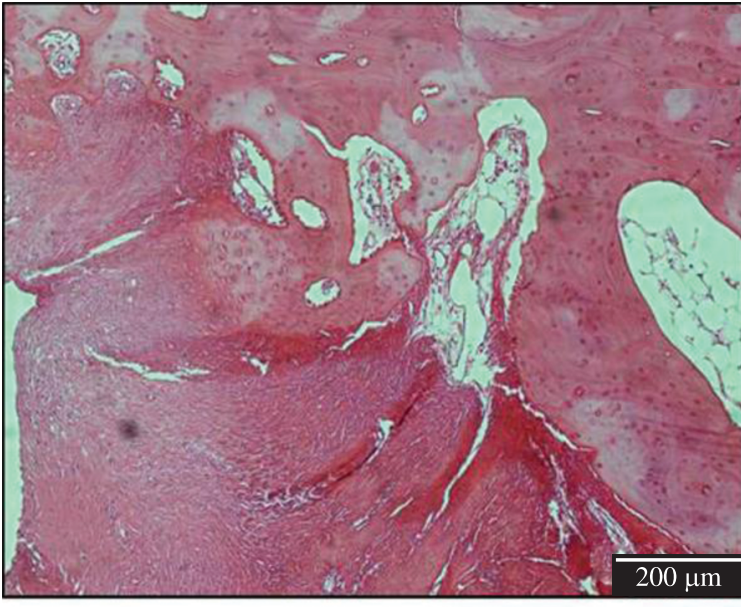

(a)

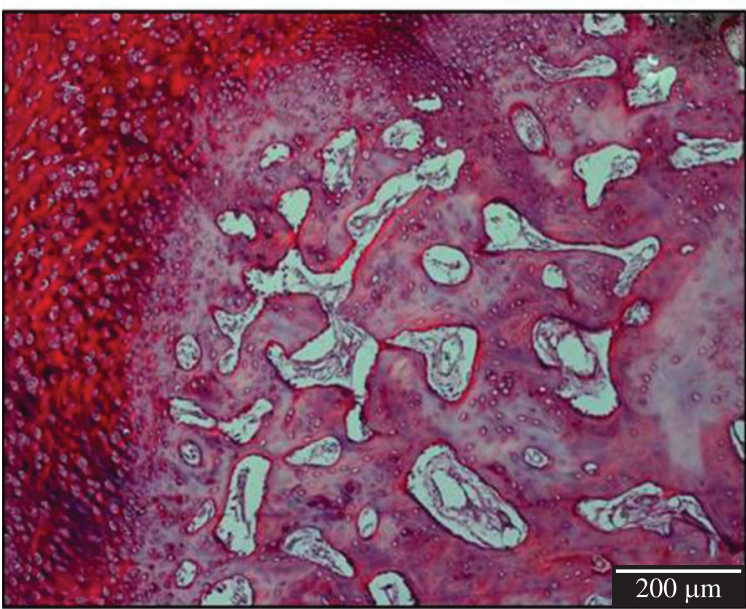

(c)

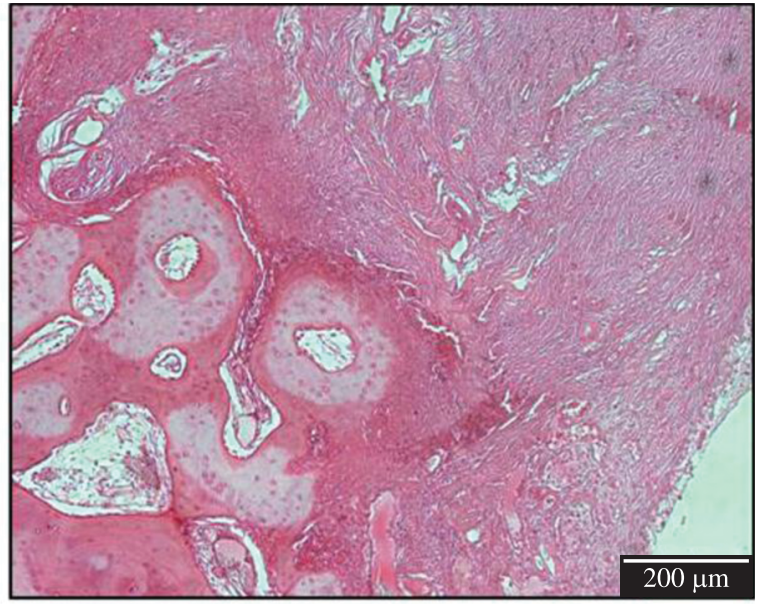

(b)

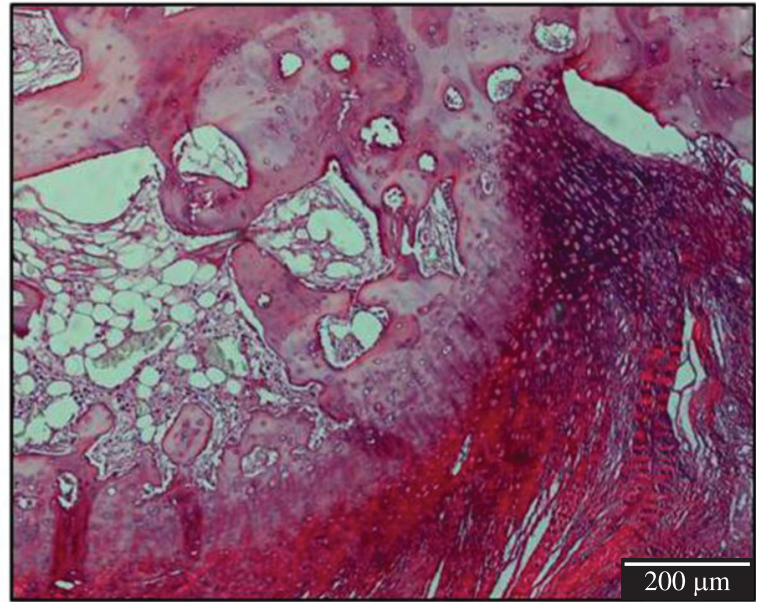

(d)

Figure 5. Histological analysis of control lesions (untreated) after 12 weeks. (a) and (b): HE staining; (c) and (d): Picrosirius red staining. Note the presence of bony neoformed tissue and extensive superficial fibrous tissue in all cases.

Fedrizzi and Duek ${ }^{28}$ showed that PLDLA/PCL-T (90/10 composition) pins were sufficiently biocompatible for bone regeneration in tibia and this polymer combination held promising prospects for osteochondral applications.

In agreement with this, recent work has shown that hybrid, biphasic frameworks can be useful for repairing osteochondral lesions ${ }^{22}$. The combination of biodegradable polymers and bioactive ceramics in a variety of composite structures is promising in this area, whereby the fabrication methods, associated cells and signaling factors determine the success of the strategies ${ }^{39}$. In this regard, the use of hydrogels can enhance osteochondral repair ${ }^{40,41}$.

Recently, Hannink et al. ${ }^{42}$ evaluated if a porous polycaprolactone-polyurethane scaffold, currently used for partial meniscal replacement in clinical practice, could initiate regeneration and repair of osteochondral defects, and if regeneration and repair were related to mechanical stimulation in New Zealand White rabbits. The results suggest that mechanical forces may not have to be applied over long periods of time to accelerate tissue formation and increase cartilage repair longevity. Osteochondral defects might be treated using porous polymer scaffolds, although several limitations need yet to be overcome.

Additionally, tissue engineering has emerged as an excellent approach for the repair and regeneration of damaged tissue, with the potential to circumvent all the limitations of autologous and allogeneic tissue repair ${ }^{43,44}$. Cell sources and biological protein incorporation methods are discussed, addressing their interaction with scaffolds and highlighting the potential for creating a new generation of bilayered composite scaffolds that can mimic the native interfacial tissue properties, and are able to adapt to the biological environment ${ }^{39}$.

Deng et al. ${ }^{45}$ evaluated the efficacy of a three-dimensional (3D) heterogeneous/bilayered scaffold, consists of gelatin, chondroitin sulphate and sodium hyaluronate $(\mathrm{GCH})$ and ceramic bovine bone (GCBB), to repair large defects in rabbit joints. In summary, this study demonstrated that a novel scaffold, comprising a top layer of $\mathrm{GCH}$, having 


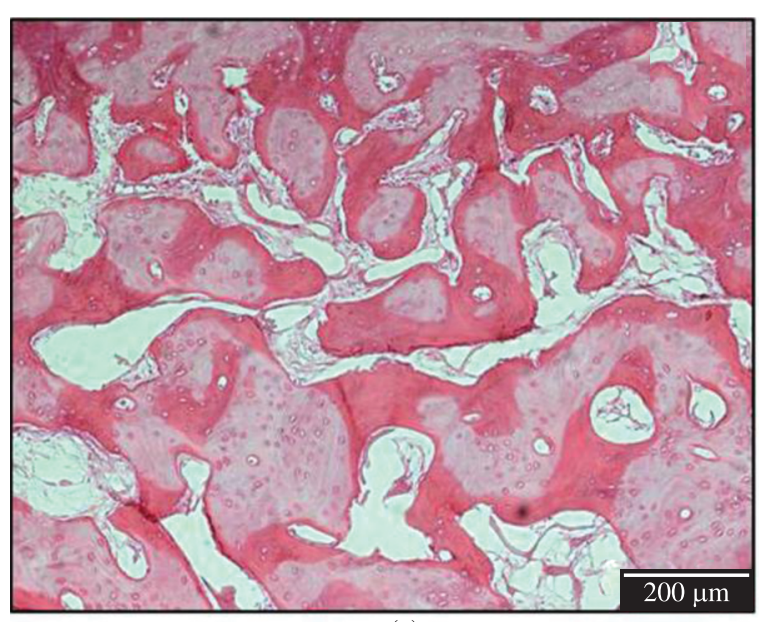

(a)

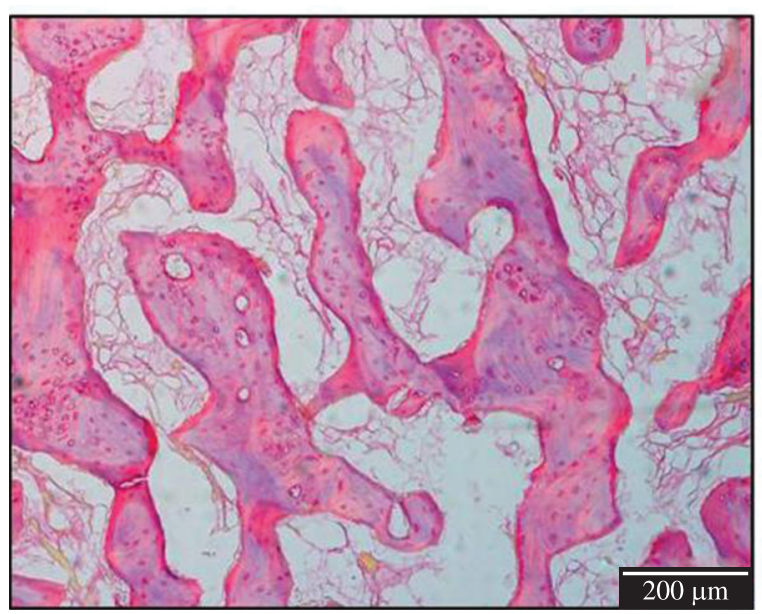

(c)

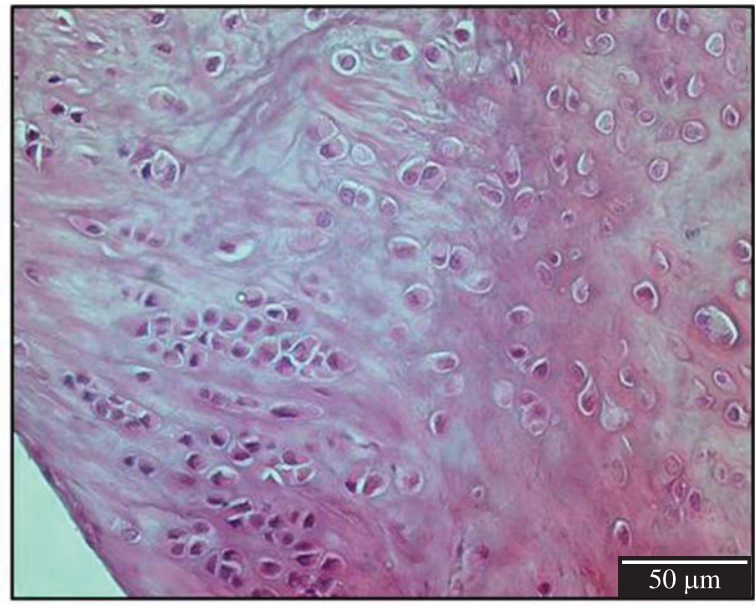

(b)

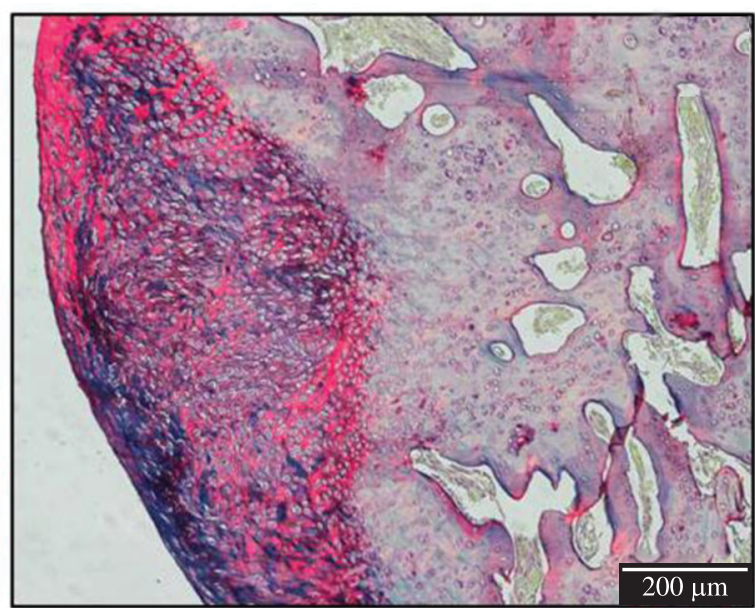

(d)

Figure 6. Histological analysis of lesions with the PLDLA/PCL-T [ng. Note the presence of bony neotissue and hyaline cartilage and the absence of giant cells associated with a foreign body reaction.

mechanical properties comparable to native cartilage, and combined with chondrocytes and bone marrow stem cells (BMSCs) could be used to repair large osteochondral defects in joints.

Furthermore, the fascinating potential of mesenchymal stem cells has recently opened new paths of research to discover how and whether these powerful entities can really contribute to tissue regeneration ${ }^{46,47}$. The first clinical trials have been published but further high quality research is needed to understand their mechanisms of action, their limits, and their clinical efficacy ${ }^{25}$.

In agreement with the criteria defined by Gogolewski ${ }^{48}$, the PLDLA/PCL-T scaffold used in this study did not induce an exacerbated foreign body inflammatory response, was not carcinogenic, mutagenic, teratogenic, toxic or allergenic and did not cause hypersensitivity or activate the complement system. Together, these properties indicate that PLDLA/PCL-T could be useful in a variety of therapeutic applications.
In contrast, the empty space seen in the control group could contribute to the greater incidence of bone fractures during healing.

However, longer implant times should be studied to evaluate the tissue regeneration and validate the hypothesis accessed.

\section{Conclusion}

The results of this study show that although bone neoformation was observed in osteochondral lesions of treated and non-treated lesions, treatment with a polymer implant markedly reduced the inflammatory response, bone necrosis and giant cell foreign body reaction compared to the control group. The protective action of the polymer scaffold probably reflected its ability to stabilize the lesion and allow the formation of hyaline cartilage. The good biocompatibility of PLDLA/PCL-T seen here indicates that this material may be useful in tissue engineering. 


\section{References}

1. Redman SN, Oldfield SF and Archer CW. Current strategies for articular cartilage repair. European Cells \& Materials Journal. 2005; 14(9):23-32.

2. Buckwalter JA, Einhorn TA and Simon SR. Orthopaedic Basic Science - Biology and Biomechanics of the musculoskeletal system. Rosemont: American Academy of Orthopaedic Surgeons; 2000.

3. Garrido LF. Avaliação do desempenho de implantes de polietileno e de fosfato tricalcio, recobertos por hidrogel, em defeitos osteocondrais no joelho de cães. [Dissertação]. São Paulo: Universidade Estadual de Campinas; 2007.

4. Swieszkowski W, Tuan BHS, Kurzydlowski KJ and Hutmacher DW. Repair and regeneration of osteochondral defects in the articular joints. Biomolecular Engineering. 2007; 24(5):489495. PMid:17931965. http://dx.doi.org/10.1016/j. bioeng.2007.07.014

5. Little K. Nature of osteopetrosis. British Medical Journal. 1969; 5(2):49-50. PMid:5776223 PMCid:1983025. http://dx.doi.org/10.1136/bmj.2.5648.49-a

6. Mankin HJ. The response of articular cartilage to a mechanical injury. The Journal of Bone and Joint Surgery. 1932; 64(3):460-466.

7. Souza TD, Del Carlo RJ and Viloria MIV. Efeitos da eletroterapia no processo da reparação da superfície articular de coelhos. Ciência Rural. 2001; 31(1):819-824. http://dx.doi. org/10.1590/S0103-84782001000500013

8. Ribeiro JL, Camanho GL and Takita LC. Estudo macroscópico e histológico de reparos osteocondrais biologicamente aceitáveis. Acta Ortopédica Brasileira. 2004; 12(1):16-21. http://dx.doi.org/10.1590/S1413-78522004000100003

9. Huntley JS, McBirnie JM, Simpson AH and Hall AC. Cutting-edge design to improve cell viability in osteochondral grafts. Osteoarthritis and Cartilage. 2005; 13(8):665-671. PMid:15964219. http://dx.doi.org/10.1016/j.joca.2005.04.007

10. Hattori K, Takakura Y, Ohgushi H, Habata T, Uematsu K and Ikeuchi K. Novel ultrasonic evaluation of tissue-engineered cartilage for large osteochondral defects - non invasive judgment of tissue-engineered cartilage. Journal of Orthopedic Research. 2005; 23(5):1179-1183. PMid:15925475. http:// dx.doi.org/10.1016/j.orthres.2005.03.014

11. Henderson I, Francisco R, Oakes B and Cameron J. Autologous chondrocyte implantation for treatment of focal chondral defects of the knee - a clinical, arthroscopic, MRI and histologic evaluation at 2 years. The Knee. 2006; 12(3):209-216. PMid:15911295. http://dx.doi.org/10.1016/j.knee.2004.07.002

12. Martin I, Miot S, Barbero A, Jakob M and Wendt D. Osteochondral tissue engineering. Journal of Biomechanics. 2007; 40(4):750-765. PMid:16730354. http:// dx.doi.org/10.1016/j.jbiomech.2006.03.008

13. Jansen EJ, Pieper J, Gijbels MJ, Guldemond NA, Riesle J, Van Rhijn LW et al. PEOT/PBT based scaffolds with low mechanical properties improve cartilage repair tissue formation in osteochondral defects. Journal of Biomedical Materials Research Part A. 2009; 89(2):444-452. PMid:18431789. http:// dx.doi.org/10.1002/jbm.a.31986

14. Anselme K. Osteoblast adhesion on biomaterials. Biomaterials. 2000; 21(7):667-681. http://dx.doi.org/10.1016/ S0142-9612(99)00242-2

15. Atala A. Tissue engineering and regenerative medicine: concepts for clinical application. Rejuvenation Research. 2004; 7(1):15-31. PMid:15256042. http://dx.doi. org/10.1089/154916804323105053
16. Duek EAR, Zavaglia CAC and Belangero WD. In vitro study of poly(lactic acid) pin degradation. Polymer. 1999; 40(23):6465-6473. http://dx.doi.org/10.1016/ S0032-3861(98)00846-5

17. ZhaoK, DengY,ChunChenJandChen GQ.Polyhydroxyalkanoate (PHA) scaffolds with good mechanical properties and biocompatibility. Biomaterials. 2003; 24(6):1041-1045. http:// dx.doi.org/10.1016/S0142-9612(02)00426-X

18. Sakata MM, Alberto-Rincon MC and Duek EAR. Estudo da interação polímero/cartilagem/osso utilizando poli(ácido lático-co-ácido glicólico) e poli(p-dionaxona) em côndilo femoral de coelhos. Polímeros. 2004; 14(3):176-180. http:// dx.doi.org/10.1590/S0104-14282004000300013

19. Motta AC. Síntese e caracterização de dispositivos de poli (L-co-DL ácido latico). Estudo da degradação in vitro e in vivo. [Tese]. São Paulo: Universidade Estadual de Campinas; 2006.

20. Duarte MAT. Estudo da influência das concentrações do PCL-T em membranas de PLDLA para ser utilizadas como dispositivos biomédicos: estudo in vitro e in vivo. [Tese]. São Paulo: Universidade Estadual de Campinas; 2009.

21. Esposito AR. Crescimento de fibrocondrócitos sobre arcabouço de PLDLA/PCL-T para aplicação como prótese de menisco. [Dissertação]. São Paulo: Universidade Estadual de Campinas; 2010.

22. Xie J, Han Z, Naito M, Maeyama A, Kim SH, Kim $\mathrm{YH}$ et al. Articular cartilage tissue engineering based on a mechano-active scaffold made of poly(L-lactide-coepsilon-caprolactone): In vivo performance in adult rabbits. Journal of Biomedical Materials Research Part B: Applied Biomaterials. 2010; 94(1):80-88. PMid:20336738.

23. Lam KH, Schakenraad JM, Esselbrugge H, Feijen J and Nieuwenhuis PJ. The effect of phagocytosis of poly(L-lactic acid) fragments on cellular morphology and viability. Journal of Biomedical Materials Research. 1993; 27(12):1569-1577. PMid:8113245. http://dx.doi.org/10.1002/jbm.820271214

24. Seal BL, Otero TC and Panitch A. Polymeric biomaterials for tissue and organ regeneration. Materials Science and Engineering Reports. 2001; 34(4):147-230. http://dx.doi. org/10.1016/S0927-796X(01)00035-3

25. Kon E, Filardo G, Roffi A, Andriolo L and Marcacci M. New trends for knee cartilage regeneration: from cell-free scaffolds to mesenchymal stem cells. Current Reviews in Musculoskeletal Medicine. 2012. Available from: <http://www.springerlink. com>. Access in: 25/07/2012.

26. Pezzin APT, Cardoso TP, Rincón MCA, Zavaglia CAC and Duek EAR. Bioreabsorbable polymer scaffold as temporary meniscal prosthesis. Artificial Organs. 2003; 27(5):428-431. http://dx.doi.org/10.1046/j.1525-1594.2003.07251.x

27. Maluf LCV, Silva D, Duek EAR and Alberto Rincon MC. Morphometrical analysis of multinucleated giant cells in subdermal implants of poly(lactic acid) in rats. Journal of Materials Science: Materials in Medicine. 2006; 17(5):481-485. PMid:16688589. http://dx.doi.org/10.1007/s10856-006-8476-7

28. Fedrizzi V and Duek EAR. Estudo de blendas de Poli(L-co$\mathrm{D}, \mathrm{L}$ ácido láctico)/Poli(caprolactona triol) para aplicações em dispositivos ortopédicos. In: Anais do $15^{\circ}$ Encontro de Iniciação Cientifica da PUC-SP; 2007; São Paulo. São Paulo: PUC; 2007. v. 1

29. Pierucci A, Duek EAR and Oliveira ALR. Peripheral nerve regeneration through biodegradable conduits prepared by solvent evaporation. Tissue Engineering. 2008; 14(5):595-606. PMid:18399734. http://dx.doi.org/10.1089/tea.2007.0271

30. Lawrence BJ and Madihally SV. Review Cell colonization in degradable $3 \mathrm{D}$ porous matrices. Cell Adhesion \& 
Migration. 2008; 2(1):9-16. http://dx.doi.org/10.4161/ cam.2.1.5884

31. Emans PJ, Jansen EJ, Van Iersel D, Welting TJ, Woodfield TB, Bulstra SK et al. Tissue-engineered constructs: the effect of scaffold architecture in osteochondral repair. Journal of Tissue Engineering and Regenerative Medicine. 2012. Available from: $<$ http://www.wileyonlinelibrary.com>. Access in: 25/07/2012.

32. Mikos AG, Sarakinos G, Lyman MD, Ingber DE, Vacanti JP and Langer R. Prevascularization of porous biodegradable polymers. Biotechnology and Bioengineering, 1993; 42(6):716-723. PMid:18613104. http://dx.doi.org/10.1002/bit.260420606

33. Shapiro F, Koide S and Glimcher MJ. Cell origin and differentiation in the repair of full-thickness defects of articular cartilage. The Journal of Bone and Joint Surgery. 1993; 75(4):532-553. PMid:8478382.

34. Shao XX, Hutmacher DW, Ho ST, Goh JC and Lee EH. Repair of large articular osteochondral defects using hybrid scaffolds and bone marrow-derived mesenchymal stem cells in a rabbit model. Biomaterials. 2006; 27(7): 1071-1080. PMid:16129483. http://dx.doi.org/10.1016/j.biomaterials.2005.07.040

35. Solchaga LA, Temenoff JS, Gao J, Mikos AG, Caplan AI and Goldberg VM. Repair of osteochondral defects with hyaluronan- and polyester-based scaffolds. Osteoarthritis Cartilage. 2005; 13(4):297-309. PMid:15780643. http://dx.doi. org/10.1016/j.joca.2004.12.016

36. Yasuda K, Kitamura N, Gong JP, Arakaki K, Kwon HJ, Onodera S et al. A Novel Double-Network Hydrogel Induces Spontaneous Articular Cartilage Regeneration in vivo in a Large Osteochondral Defect. Macromolecular Bioscience. 2009; 8(9):307-316. PMid:19031389. http://dx.doi. org/10.1002/mabi.200800223

37. Baptista MP. Engenharia de tecidos de defeitos osteocondrais combinando estratégias de design de suportes processados por agregação de partículas e de libertação controlada de agentes bioactivos. [Tese]. Braga: Universidade do Minho; 2008.

38. Oliveira JM, Rodrigues MT, Silva SS, Malafaya PB, Gomes $\mathrm{ME}$, Viegas CA et al. Novel hydroxyapatite/chitosan bilayered scaffold for osteochondral tissue-engineering applications: Scaffold design and its performance when seeded with goat bone marrow stromal cells. Biomaterials. 2006; 27(36):6123-6137. PMid:16945410. http://dx.doi.org/10.1016/j. biomaterials.2006.07.034

39. Nooeaid P, Salih V, Beier JP and Boccaccini AR. Osteochondral tissue engineering: scaffolds, stem cells and applications. Journal of Cellular and Molecular Medicine. 2012. Available from: <http://www.wileyonlinelibrary.com>. Access in: $25 / 07 / 2012$.

40. Hui JH, Ren X, Afizah MH, Chian KS and Mikos AG. Oligo[poly(ethylene glycol)fumarate] Hydrogel Enhances Osteochondral Repair in Porcine Femoral Condyle Defects. Clinical Orthopaedics and Related Research. 2012. Available from: <http://www.clinorthop.org>. Access in: 25/07/2012.

41. Khanarian NT, Jiang J, Wan LQ, Mow VC and Lu HH. A hydrogel-mineral composite scaffold for osteochondral interface tissue engineering. Tissue Engineering Part A. 2012; 18(5-6):533-45. PMid:21919797. http://dx.doi. org/10.1089/ten.tea.2011.0279

42. Hannink G, De Mulder EL, Van Tienen TG and Buma P. Effect of load on the repair of osteochondral defects using a porous polymer scaffold. Journal of Biomedical Materials Research Part B: Applied Biomaterials. 2012. Available from: <http:// www.wileyonlinelibrary.com>. Access in: 25/07/2012.

43. LaPorta TF, Richter A, Sgaglione NA and Grande DA. Clinical relevance of scaffolds for cartilage engineering. Orthopedic Clinics of North America. 2012; 43(2):245-54. PMid:22480473. http://dx.doi.org/10.1016/j.ocl.2012.02.002

44. Panseri S, Russo A, Cunha C, Bondi A, Di Martino A, Patella $\mathrm{S}$ et al. Osteochondral tissue engineering approaches for articular cartilage and subchondral bone regeneration. Knee Surgery, Sports Traumatology, Arthroscopy. 2012; 20(6):1182-91. PMid:21910001. http://dx.doi.org/10.1007/s00167-011-1655-1

45. Deng T, Lv J, Pang J, Liu B and Ke J. Construction of tissueengineered osteochondral composites and repair of large joint defects in rabbit. Journal of Tissue Engineering and Regenerative Medicine. 2012. Available from: <http://www. wileyonlinelibrary.com>. Access in: 25/07/2012.

46. Liu M, Xiang Z, Pei F, Huang F, Cen S, Zhong G et al. Repairing defects of rabbit articular cartilage and subchondral bone with biphasic scaffold combined bone marrow stromal stem cells. Zhongguo Xiu Fu Chong Jian Wai Ke Za Zhi. 2010; 24(1):87-93. PMid:20135980.

47. Matsumoto T, Okabe T, Ikawa T, Iida T, Yasuda H, Nakamura $\mathrm{H}$ et al. Articular cartilage repair with autologous bone marrow mesenchymal cells. Journal of Cellular Physiology. 2010; 225(2):291-5. PMid:20458744. http://dx.doi. org/10.1002/jcp. 22223

48. Gogolewski S. Bioresorbable polymers in trauma and bone surgery. Injury. 2000; 31(4):28-32. http://dx.doi.org/10.1016/ S0020-1383(00)80020-0 